[Student's Name]

[Date]

[English 400 Level Course]

[Instructor]

Free Will and Agency Hierarchies within Chaucer's Troilus and Criseyde

Readers of Chaucer's Troilus and Criseyde are thrust into a different world and societal structure: the world of Troy under siege, and a society that is governed by preoccupations regarding preserving individual honor and dignity. These preoccupations are largely found within the public sphere of Troy's culture, given the fact that there is not much private time, especially for females in the population. Josephine Koster's article "Privitee, Habitus, and Proximity" makes this last observation the focus of its argument, noting that modern audiences of Troilus and Criseyde do not fully understand the differing division of the public and private spheres of Troy (or how the latter of these spaces is rarely inhabited) from the organization of such spheres today. This lack of understanding can cause confusion regarding each characters' level of agency and free will in society and within their relationships with other characters. Looking specifically at Troilus, Criseyde, and Pandarus, we can see that there is a hierarchy both of free will and of agency amongst the characters in Book IV (and in previous books), which is then changed by Criseyde's move to the Greek camp in Book V of the poem. In Book IV, it is clear that Pandarus, who takes on a pseudo-narrator role, largely controls the movements and interactions of Troilus and Criseyde. However, when Criseyde moves away from Troy, outside the walls of Pandarus' influence, he loses power over her actions, allowing her to gain agency (though 
her free will is still limited by social constraints) while Troilus is still servant to Criseyde and Pandarus' control.

It is important to first identify the differences between agency and free will within Troilus and Criseyde: they are subtle, yet each holds its own hierarchy structure within the poem. In this paper, I will defer the definition of agency to Merriam-Webster, which notes that it is "the capacity, condition, or state of acting or of exerting power," or "a person or thing through which power is exerted or an end is achieved" (Agency). With this mindset, we see that agency involves the decision to make a choice, given that a choice is able to be made. Meaning, if a character is given the opportunity to take two courses of action, their agency is determined by whether or not the character makes the choice, or whether they defer to someone else to make the choice for them.

Free will, on the other hand, determines whether the character has the right to make a choice in the first place. Looking at this definition, we can see that there are multiple kinds of free will: political, gender, societal, and a more nebulous "love" free will. Political and societal free will are much determined by the culture structure the characters are in, which is why Criseyde's free will levels change once she is outside the walls of Troy (as we will discuss later in the paper). Gender free will is, much as the name suggests, based solely on gender; though the gender free will is certainly dependent upon the societal norms and regulations, it is apparent that females in both Troy and the Greek camp are inferior to males insofar as their actions are limited by constraints placed on them due to their femaleness. The "love" free will is a bit harder to define: this idea has more to do with the ability to choose whom to love. Looking specifically at Troilus, we see that he has limited free will in this sense, since he is love-struck by a higher power, unlike the other characters. 
A poignant example of the differences between agency and free will come with Troilus' love of Criseyde: as J. Mitchell notes in his article "Romancing Ethics in Boethius, Chaucer, and Levinas," "[Troilus] may be free to choose (though the text does not concede total freedom even in this regard), but he is not at any rate free of the choice" (108). Troilus holds agency over his decision to love Criseyde, insofar as he is able to make the choice whether to love her by himself, but he does not have free will in love. The decision must be made, but Troilus holds the power to decide who makes the decision. This situation introduces "the possibility of a responsibility that is not voluntary or contractual - in other words, the possibility that ethics arises out of fortune rather than freedom" (Mitchell 107). The idea of fortune is closely related to that of free will: Mitchell, here, argues that the ethics of Troilus and Criseyde (discussed here as merely the actions and motivations of the characters) are able to be determined by free will, or lack thereof, rather than the agency of the characters. Jelena Marelj claims, taking Mitchell's idea a step further, that the causes of the relationships between characters in Troilus and Criseyde "oscillates between voluntarism and cosmic determinism" (207). Troilus, in the previous example, held agency as far as the outcome of the decision was involved, but did not have free will to decide whether a decision was to be made.

Yet in Book IV, we see Troilus subordinate his agency to Criseyde when her trade to the Greeks is publicly announced. Here, Troilus' instincts to stop the trade are overpowered by his reason and subordination to Criseyde:

But Resoun seyde him, on that other syde, 'Withouten assent of hire ne do nat so, Lest for thi werk she would be thy fo, 
And seyn that thorugh thy medlynge is iblowe

Youre bother love, there it was erst unknowe.' (IV.164-8)

In this quotation, we see Troilus consciously subordinate himself to Criseyde's will, thereby placing himself under her in the hierarchy of agency. "Resoun," which seems logical under social constraints, influences him; Troilus justifies not speaking out by noting that Criseyde may not want him to announce their relationship in a public sphere, and may lose her love if he goes against her wishes. Despite Troilus' love for Criseyde, his consciousness of her potential wishes triumphs over his own desires to have her stay with him in Troy: her honor is more important to him than his own hope of staying with her.

This fact brings to the forefront the difference between Troilus' agency and his political free will. He notes in the poem that he would be able to stop the trade due to the fact that his father is the king of Troy:

I sholde han also blame of every wight, My fadres graunt if that I so withstood, Syn she is changed for the townes good.

'I have ek thought, so it were hire assent, To axe hire at my fader, of his grace; ...

For syn my fader, in so heigh a place As parlement hath hire eschaunge ensiled, He nyl for me his letter be repeled. (IV.551-555, 558-560) Troilus is aware that he holds the power to ask his father for Criseyde, and that his father has both the agency and the free will to release Criseyde from the trade. Yet Troilus, in the 
last portion of the excerpt, realizes that his father would not execute his power for this matter. Instead of giving up his agency and free will to King Priam, Troilus decides against this course of action, reasoning that asking his father to renounce his decree would bring dishonor to Criseyde, and "as nolde God but if I sholde have / Hire honour levere than my lif to save!" (IV.566-7). Troilus would rather die than bring dishonor to Criseyde's name, and it is precisely this fact that shows the audience the importance placed on Criseyde's honor and integrity within society, her place in the social hierarchy. This idea is somewhat standard, and can be seen in Chaucer's work, when priority is given to "moral integrity over autonomy and agency" (Mitchell 102). Given this, it is clear as to why Troilus would subjugate his agency to Criseyde's: not necessarily because he has less of it, but because the preoccupation with honor and moral integrity hold a higher priority in Troy's societal structure than agency does.

Criseyde's preoccupations with her own honor are understandable, and the priority she gives the topic throughout the poem make it clear as to why Troilus would not want to put her dignity at risk either. As Josephine Koster notes, "as a politically suspect person [Criseyde] must seem humble and not fail to appear at community ... lest she be thought even more unreliable; as the daughter of a traitor, she cannot flaunt her status as a woman 'well at ese' lest she be thought to have profited from her father's treason" (Koster 81). It is apparent that Criseyde is in a precarious situation due to her father's actions: she has been left without a father guardian and now must navigate the dangerous Troy-under-siege either alone or under her uncle's guidance. Criseyde must not vaunt her status as an independent woman (even under her uncle's chaperonage, she has more freedom over her life than many of the other women in Troy), yet cannot stay out of the public eye for fear of 
society's disapproval and suspicion regarding her actions. An "observance of the rules of social etiquette is particularly important to a woman whose father violated them by his treachery" (Koster 87).

Criseyde's duties to remain proper illustrate her restricted free will in regards to gender: as a woman, she does not have the choice to be alone, except for small amounts of time, for fear that her reputation will be tarnished. Koster notes that Criseyde does a "great deal of private maneuvering [which] takes place in very public spaces," showing the audience that the character is "properly aware of the social niceties" that she must follow in order to continue to be accepted in society after her father's traitorous actions $(85,82)$. It is exactly these social constraints that force Criseyde's agency to bend to Pandarus' will. In the especially perilous bedroom scene in which Pandarus traps Criseyde in his own bedchamber, we see that "Criseyde has little choice: if she publicly accuses Pandarus of bringing Troilus to her bed, she destroys her own honor. Entrapped in her uncle's (and guardian's) bedchamber, her women locked away from her, her options are limited" (Koster 87-8). Pandarus, by manipulating Criseyde into this situation, forcibly strips her of her agency, forcing her into a state with unknown social rules, and thus a higher chance of creating dishonor.

Unlike Troilus, who willingly gives up his agency to Criseyde, she involuntarily loses her control (and with it, both her free will and agency) over courting situations at her uncle's hands. We see that "the constraints of her social situation force her to go along with the encounter that her guardian has so carefully orchestrated" (Koster 86). What Koster emphasizes is Pandarus' planned manipulation: the situations he forces Criseyde in are not accidents, but rather meticulously planned so as to trap her by social mores. We see again, 
with this example, the tension between free will and agency within Troilus and Criseyde.

Originally, Criseyde has both free will and agency over who to love, but through being manipulated by Pandarus, we see that both of these levels are depleted: Criseyde is still, to a certain extent, free to decide whether to love someone, and who to love. Troilus, as discussed previously, holds agency in his love life, but no free will. Even Troilus realizes his lack of free will, noting that "for al that comth, comth by necessitee: / Thus to ben lorn, it is my destinee" (IV.958-9). His resignation to fate in his life relates most strongly to his love life (when this declaration was made, he is mourning the announcement of Criseyde's trade to the Greeks), but it is noteworthy to realize that Troilus himself is cognizant of his lack of free will regarding certain aspects of his life.

We find, then, that we end Book IV with the following hierarchy structure:

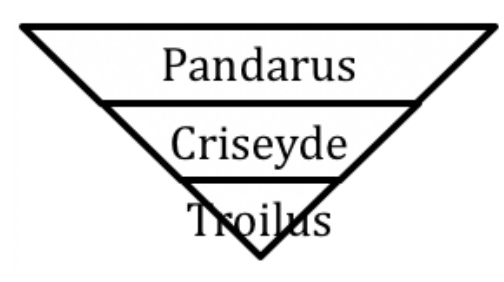

Figure 1: Agency Hierarchy

From the previous examples, it is clear that Troilus places his agency second to Criseyde's, who is subjugated to Pandarus' agency by his role of chaperone, as well as the agency limitations on females. Marelj, however, claims that Criseyde is very much a "willful agent of her own actions," causing the audience to wonder whether Criseyde holds more power than she appears to (213). With this notion, the argument could be made that Criseyde should be placed at the top of the hierarchy, yet if this were the case, Criseyde would not necessarily be constrained by Pandarus' situational manipulation. Expanding upon this idea, if Criseyde did not want to risk her honor, she would hold enough agency over 
Pandarus to free herself from the situations, or be able to limit Pandarus' actions involving her. Since this is not the case, we can safely assume that Criseyde's agency is inferior to Pandarus'.

We see that the free will structures appear to look like the following:

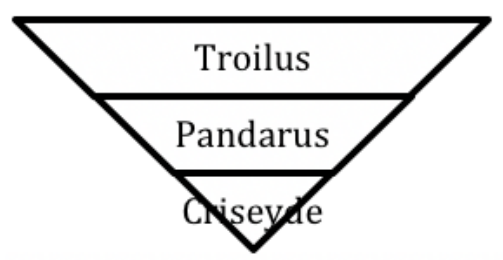

Figure 2: Political

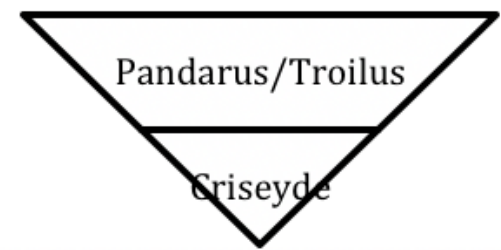

Figure 3: Social/Gender

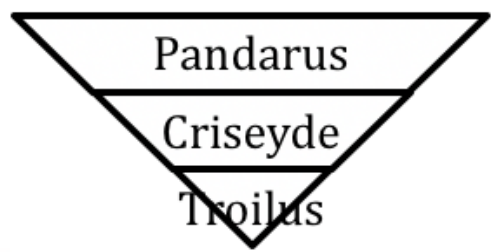

Figure 4: Love

Troilus, through his father, has the most political free will, with Pandarus holding the middle hierarchical position due to his gender. Criseyde, as a woman, and as the daughter of a traitor, holds a precarious role in the political realm. Regarding the social/gender free will (which, though different, has the same hierarchy), we see that Pandarus and Troilus are on equal footing because of their male gender, whereas Criseyde is beneath them due to her female status within society: she therefore has more constraints placed on her actions and the decisions she is able to make within society. We see that Pandarus' role as guardian immediately elevates his social free will to higher than that of Criseyde: his ability to manipulate the social situations she is placed in (e.g. the bedroom scene, or the garden scene) shows the audience of the poem that Pandarus holds more power in the social realm than Criseyde does.

The final hierarchy (that of love free will), definitely has Troilus on the bottom, as we have discussed, due to his inability to not be in love, insofar as he is love-struck from a higher being. Criseyde and Pandarus' positions require a bit more justification. Criseyde holds the power to not have a husband, as evidenced by her widow status at the beginning 
of the poem; as long as she has a guardian, she holds an acceptable place in society. It is this qualification, however, that places her in a lower position of love free will than Pandarus, who has no such stipulations for his single status. Pandarus, as a male, is able to be single in society without justification. Criseyde, also, has the affections of Troilus to handle, and though she certainly holds the power to deny his advances, her position in society and the given agency hierarchy suggests that Pandarus' control over her status would necessitate the relationship with Troilus. As Koster notes, “...public and private have been commingled by Pandarus' skilled manipulation of domestic space, and now Criseyde is as committed to the private exchanges as are Troilus and Pandarus" (Koster 86). Through her lower position in all of the hierarchy structures, Criseyde becomes involved and committed to the lover's relationship solely because Pandarus forces her into the situations that instigate the relationship.

We can see, however, that Criseyde's position within the agency hierarchy changes once she leaves the walls of Troy, and subsequently, the walls of Pandarus' control. We see that outside the walls of Troy, Pandarus loses some authority over the actions of both Troilus and Criseyde. When Troilus is leading Criseyde to the trade spot in Book V, he tries to gain agency through an internal monologue:

Whi nil I make atones riche and pore

To have inought to done er that she go?

Whi nil I brynge al Troie upon a roore?

Whi nyl I slen this Diomede also?

Whi nyl I rather with a man or Two

Stele hire away? Whi wol I this endure? 
Whi nyl I helpen to myn owen cure? (V.43-9)

Troilus' repeated use of "whi nyl" ("why not") suggests to the readers that he regrets his lack of action within the walls of Troy: he repents not trying more to stop the trade, even suggesting bringing "al Troie upon a roore," despite his earlier claim that he was not going to bring violence to Troy as a result of his displeasure (V.45).

Pandarus' absence allows Troilus to attempt to gain agency insofar as Troilus is only subjected to Criseyde's control at this point in the poem, instead of both Criseyde and Pandarus' authority. Yet we see that Criseyde's control is still very much present in influencing his decisions: "He hadde in herte alweyes a manere drede / Lest that Criseyde, in rumour of this fare, / Sholde han ben slayne" (V.52-4). Troilus prioritizes Criseyde's fate above his own, and thus above their collective fate. He seems to diminish the fact that he is the king's son, and holds some influence over the wishes of common society members (as discussed earlier). We see that the poet tries to give Troilus authority over his thoughts by noting "lo, this was al his care" (V.54). Yet having this realization come after his monologue draws attention to the fact that Troilus' course of action is determined, directly or indirectly, by Criseyde.

Criseyde's move to the Greek camp allows her freedom from Pandarus' situational manipulations. Though she is in a foreign societal structure, Criseyde is ultimately outside the reign of Pandarus' power. We can see, however, that when Troilus returns from dropping Criseyde at the trade spot, he immediately is under Pandarus' control once more, and the small amount of agency he gained while outside the walls of Troy is stripped away. Looking at the encounters between Pandarus and Troilus while they are discussing Criseyde's promised return to Troy, it is apparent that Troilus continues to believe that she 
will be true to her word, even when it apparent that Criseyde's return is improbable. Though Pandarus tries to persuade Troilus to forget about his niece, it appears that his control only goes so far as to make Troilus fall in love, and not out of it. This limitation on his power and agency over Troilus concerns him: Pandarus, we see, is able to manipulate situations that play to Troilus' love destiny (insofar as Pandarus' actions do not go against the lack of love free will given to Troilus), but is wholly unable to reverse the process. Since Troilus does not have a choice to not love, and since he has chosen to love Criseyde (much thanks to Pandarus' manipulations), Pandarus is unable to reverse his actions from earlier in the poem.

Pandarus, in these encounters, expressed disapproval for his niece's actions, but the reader must wonder whether he is an enraged uncle, shamed by his family member's actions, or whether he is only putting up that front. To expand upon the latter option, we can claim that Pandarus is upset at his loss of control, his loss of agency, in the Troilus/Criseyde relationship. Though he may be upset at Criseyde's actions, he is primarily distraught because she has changed the hierarchy of power previously set up in the poem.

As mentioned before, Criseyde gains agency when she leaves the walls of Troy. In Book V of Troilus and Criseyde, we see Criseyde leave for the Greek camp and ultimately gain some control over her own destiny. Pandarus is no longer around to manipulate her into doing what he wants: she is free (to a certain extent) to choose what she does. Criseyde lacks a chaperone in the Greek camp, interesting considering that it would be expected that she would have a chaperone once she is reunited with her father. Looking further, the swap of chaperone status is noteworthy: when Criseyde is in Troy, the audience expects her to 
not have a male chaperone (since her father abandoned her in the city and she is a widow), yet Pandarus steps into the role and fulfills it to an alarming degree. Yet as soon as Criseyde leaves the walls of Troy to live with her father, she is without a chaperone - a curious situation, since her father was so intent on being reunited with his daughter. We see that Criseyde's lack of chaperonage in the Greek camp places her in a nearly as precarious situation as she was in during the bedchamber scene: there is no guarantee for her status or chastity, and the aspect of the "foreign" places her in a wholly unknown situation.

Comparing the agency and free will charts from Book IV to the rearranged ones in Book V, we find that not much has changed, other than the agency hierarchy, which now appears to be:

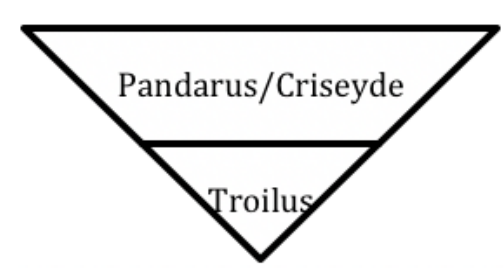

Figure 5: Agency in Book V

Criseyde is able to manipulate situations on her own, and Pandarus (as seen by his lack of power in getting Criseyde to come back to Troy) loses power in relation to Criseyde. It is important to note that, though the diagram shows Pandarus and Criseyde within the same agency sphere, they are not. Criseyde still holds power over Troilus, evidenced by his obsession with her return and his resignation to her will in the early lines of Book V, but she is now situated within a Greek agency realm. Pandarus remains in the Troy agency sphere, a realm that Criseyde has left, ultimately allowing for her freedom, since he cannot join the Greek realm to exert power over her.

With this knowledge, it is apparent that Criseyde has gained agency from Pandarus, disrupting the prior hierarchy of power, yet is still unable to have complete free will in the 
Greek camp. Her women, who acted in Troy as a barrier to guard her honor, no longer surround Criseyde. Instead, she is exposed: she stands to face the Greek community alone that is, until Diomede steps in.

As Koster suggests, Criseyde succumbs to Diomede not necessarily to betray Troilus, but to return to a sense of normalcy: "a relationship with Diomede restores her to a social position and codes of behavior that she understands ... in doing so, she protects her estate at the expense of her honour" (Koster 89). In order to navigate the foreign Greek norms, Criseyde must associate herself with Diomede, who gives her social stability much like Pandarus did in Troy. Her willingness to submit to Diomede's wishes certainly suggests that Criseyde voluntarily places herself as an inferior to his agency, but if we take this as truth, we must ask: does Diomede take possession of the agency and power that Pandarus once held over Criseyde? Or does the fact that he does not gain this agency through manipulation differentiate him from the "overbearing, boundary-crossing uncle" Criseyde had in Troy? 


\section{Works Cited}

"Agency." Meriram-Webster.com. Merriam-Webster, n.d.. Web.

Chaucer, Geoffrey. Troilus and Criseyde. Ed. Windeatt. London: Penguin Classics, 2003. Print.

Koster, Josephine A. "Privitee, Habitus, and Proximity: Conduct and Domestic Space in Chaucer's Troilus and Criseyde." Essays in Medieval Studies. 24. (2007): 79-91. Web.

Marelj, Jelena. "The Philosophical Entente of Particulars: Criseyde as Nominalist in Chaucer's Troilus and Criseyde." Chaucer Review. 47.2 (2012): 206-221. Web.

Mitchell, J. Allen. "Romancing Ethics in Boethius, Chaucer, and Levinas: Fortune, Moral Luck, and Erotic Adventure." Comparative Literature. 57.2 (2005): 101-116. Web. 